UDC $636.1:[575.17: 577.213 .3]$

\title{
GENETIC STRUCTURE OF DIFFERENT EQUINE BREEDS BY MICROSATELLITE DNA LOCI
}

\author{
A. V. Shelyov ${ }^{1}$, K. V. Kopylov ${ }^{1}$, S. S. Kramarenko ${ }^{2}$, A. S. Kramarenko ${ }^{2}$ \\ ${ }^{1}$ Institute of Animal Breeding and Genetics NAAS, \\ 1, Pohrebniaka Str, Chubynske village, Kyiv region, Ukraine, 08321 \\ ${ }^{2}$ Mykolayiv National Agrarian University, Mykolayiv, \\ 9, Georgiy Gongadze Str., Ukraine, 54020 \\ E-mail: shelyov@gmail.com
}

Received March 24, 2020 / Received April 21, 2020 / Accepted July 20, 2020

\begin{abstract}
Aim. Our work was aimed at the evaluation of genetic diversity of three domestic equine breeds which differ by the history of their formation and use. Methods. Genotyping of DNA samples of three breeds of horses, namely, Hucul (78 animals), Thoroughbred (51 animals) and Ukrainian Saddle Horse (152 animals), was conducted by 11 microsatellite loci, recommended by the International Stud Book Committee (ISBC) and the International Society for Animal Genetics (ISAG). The mathematical analysis involved parametric and non-parametric methods of statistics. Results. The results of polymorphism analysis of the gene funds for Hucul, Thoroughbred and Ukrainian Saddle horses by 11 microsatellite DNA loci were first presented in Ukraine. It was demonstrated that the study of microsatellite DNA loci allows both determining the reliability of origin of pedigree animals and controlling population processes in different breeds and the polymorphy of the very breeds. Conclusions. The molecular and genetic analysis of equine breeds, differing by their provenance, demonstrated specificities of genetic structure of each breed, which correspond to the formation history of their gene funds. The populational-genetic analysis using different mathematical methods is recommended for the purposes of evaluating and forecasting microevolution processes, controlling gene fund formation both during the breeding work and within the system of preserving genetic biodiversity.
\end{abstract}

Key words: horses, DNA markers, microsatellites, polymorphism, allele pool, gene pool, population genetics.

DOI:

\section{INTRODUCTION}

In recent decades, considerable achievement in the development of molecular-genetic technologies has triggered the study of genomes of livestock which has conditioned genetic progress in animal breeding significantly (Khare V et al., 2017).

Contrary to other industries, horse-breeding traditionally employs the individual system of assorting and selection of animals, thus modern molecular and genetic methods were found to be an indispensable instrument in determining the range of population and breed variability, in the issues of studying phylogenesis, the degree of genetic similarity, the analysis of microevolution processes. The study of genetic specificities of stud and local breeds became the basis for the elaboration of genetic monitoring methods in horse breeding.

\footnotetext{
(C) A. V. SHELYOV, K. V. KOPYLOV, S. S. KRAMARENKO, A. S. KRAMARENKO, 2020
}

Genetic monitoring allows evaluating and controlling genetic diversity on both phenotypic and genotypic levels (Khrabrova L et al., 2014). The management of genetic diversity is a key factor of any program of preserving species and breeds to protect genetic resources of animals (Gupta A et al., 2015, Vostrá Vydrová H et al., 2015, Khanshour A et al., 2015), which should ensure preservation of the maximal genetic variability and future adaptation potential of the breeds (Rukavina D et al., 2015, Winton C et al., 2013).

One of modern genetic monitoring methods is individual and population evaluation of genetic structure of horses by microsatellite DNA loci (STR) which allows for genetic examination of the origin of animals with up to $99.9 \%$ probability of reliability. In addition, microsatellite markers are a reliable instrument in studying the genetic structure and phylogenesis of breeds and populations of horses, including the as- 
sessment of the diversity degree and determination of genetic similarity, differentiation of genealogical structure of the breed, assessment and control of inbreeding, diagnostics of hereditary anomalies and diseases (SCID (Severe Combined Immunodeficiency), PSSM (Polysaccharide Storage Myopathy), HYPP (Hyperkalemic Periodic Paralysis), JEB (Junctional Epidermolysis Bullosa), GBED (Glycogen Branching Enzyme Deficiency), OLWS (Overo Lethal White Syndrome), etc.) (Khrabrova L A et al. 2014, Putnová L et al., 2019).

Hucul breed (HB) belongs to indigenous mountain breeds of the Carpathian region. The first records of this breed are dated 1603, though it is impossible to state the exact date of its formation. The breed was selected via cross-breeding of mountain horses from Bukovyna, Halychyna and Hungary with Norian type horses - Haflinger and Pinzgauer, as well as Oriental horses. There is a hypothesis that Hucul horses are descendants of Tarpans. In the opinion of M. Hollander, the highest impact on the creation of the Hucul breed was made by Przewalski's horses and Tarpans (Holovach MY, 2013). Starting from 1979, the Hucul breed has been in the FAO program of preserving the genotypes of aborigine and primitive breeds of animals. To ensure the unified method of breeding, the Hucul International Federation (HIF) was established in 1994 (Holovach MY, 2012).

The Thoroughbred breed (TB) is one of the fastest breeds in the world, currently bred in 70 countries. This breed was developed in England in XVII-XVIII centuries via cross-breeding of Arabian and other Oriental studs and native mares. The first Thoroughbred Studbook was published in 1791, and since then only the method of purebred breeding was applied to breed these animals (Khrabrova LA et al., 2019).

The Ukrainian Saddle horse (USH) was created in Ukraine in 1945-1990 via reproductive breeding of West-European equine breeds. The Thoroughbred, Hungarian, Russian Saddle Horse, Hanoverian and Arabian breeds were selected to create this breed. The result of this breeding was a breed, nicely suitable for classic kinds of equestrian sport - dressage, competitions and eventing (Bondarenko OV, 2008).

The preservation of equine populations mainly depends of effective headcount of the breed and the level of genetic diversity, which ensures necessary adaptive qualities and the ability to reproduce in a wide range of unfavorable conditions in terms of food and natural environment (Putnova L et al., 2019).
The study of population-genetic regularities in small and isolated populations with unique genetic and phenotypic value are of special interest (Mackowski M et al., 2015) since it ensures rather adequate evaluation and maintenance of genetic diversity level (Dubin OV, 2009). The impact of factors, breaking the genetic balance (genetic drift, bottleneck, accidental death of animals, etc.) in such populations can be traced easily (Duru S, 2017, Seyedabadi HR, 2017).

Thus, to evaluate genetic diversity within molecular-genetic monitoring, we conducted the study of the specificities of genetic structure of three equine breeds, which differ both in the history of their formation and use, namely, indigenous - Hucul breed, one of the oldest - Thoroughbred and a newly created - Ukrainian Saddle Horse.

\section{MATERIALS AND METHODS}

The molecular-genetic analysis was conducted using the biomaterial samples, taken from the horses of Hucul, Thoroughbred and Ukrainian Saddle breeds.

In the studies, the biological material from 281 horses was used from the following breeds: Hucul (Polonynske private farm, Transcarpathia region; Varto LLC, private agricultural farm Zarichchia, ASC Silskyi hospodar, Ivano-Frankivska region, 78 animals), Thoroughbred (private owners, 51 animals) and Ukrainian Saddle Horse (private owners, members of the Association for Promotion of Equestrian Sport Development in Ukraine, 152 animals).

Laboratory testing. The blood was sampled from the jugular vein using double-ended needles Venoject and vacuum tubes and holders Venosafe (Terumo, Belgium) following the standard method in accordance to the manufacturer's recommendations in sterile conditions. Genomic DNA was extracted with the DNA-sorb B Kit (AmpliSens, Russia) following manufacturer's instructions. Agarose gels $(1.5 \%)$ and Lambda DNA Gibco $\operatorname{Brl} \lambda$ weight standards were used for verification of DNA integrity. DNA concentration was measured with a NanoDrop 2000c spectrophotometer (Thermo Fisher Scientific v1.1.). The studies on the genetic structure were conducted using the following equipment: the polymerase chain reaction (PCR) was conducted using AB 2720 Thermal Cycler (Applied Biosystems, USA). Polymerase chain reaction (PCR) conditions were optimized from the recommended StockMarks ${ }^{\circledR}$ for Horses kit protocol (Applied Biosystems, USA) (Table 1, 2).

The amplified DNA was separated by the method of capillary gel electrophoresis at ABI Prism 3130 Ge- 
netic Analyzer (Applied Biosystems, USA). The registration of the obtained graphic results was done using programs Run 3130 Data Collection v.3.0 (Applied Biosystems, USA) and GeneMapper 3.7 (Applied Biosystems, USA). Genotyping of samples was performed using the 11 microsatellites (HTG04, HMS06, HTG06, AHT04, ASB23, ASB17, CA425, HTG07, HMS03, VHL20, and HMS07) from the panel recommended by the International Society for Animal Genetics (ISAG) for identity and parentage testing (van de Goor LHP et al., 2010) (Table 3).

Mathematical-statistical analysis. The following estimations were done to evaluate genetic diversity (in terms of specific MS-DNA loci): actual number of genotypes (NG) and number of breed-specific genotypes $\left(\mathrm{NG}_{\text {unik }}\right)$.

As the sampling volumes were not equal, we used the non-parametric method of Chao A. (Chao A, 1984) to calculate the potential number of genotypes (at $n \rightarrow \infty$ ): $\mathrm{NG}_{\text {Chao }}=\mathrm{NG}+\left[\left(\mathrm{NG}_{1}\right)^{2} /\left(2 * \mathrm{NG}_{2}\right)\right]$, where $\mathrm{NG}_{1}$ - number of genotypes, determined once; and $\mathrm{NG}_{2}-$ number of genotypes, which were determined twice.

To evaluate allelic diversity, we used the value of the number of the determined alleles $(\mathrm{Na})$ and the effective number of alleles (Ae), calculated in GenAIEx v. 6.5 (Peakall R, Smouse PF, 2012).

In addition, HP-rare v.1.0 program (Kalinowski ST, 2005) was used to obtain the estimates of allelic diversity $\left(\mathrm{AR}_{50}\right)$ and number of breed-specific alleles $\left(\mathrm{PAR}_{50}\right)$ for 50 randomly selected diploid animals from each sample which ensured accurate comparison of allelic diversity regardless of the sample size.

The value of observed heterozygosity (Ho), expected heterozygosity $(\mathrm{He})$ and inbreeding index (Fis) for 11 MS-DNA loci of horses from three breeds was also obtained in GenAIEx v. 6.5 (Peakall R, Smouse PF, 2012).

GENEPOP program (Rousset F, 2008) was used to check the correspondence between the distribution of genotype frequencies and Hardy-Weinberg equilibrium (HWE) regarding 11 MS-DNA loci of horses from three breeds using the algorithm of Markov chain Monte Carlo (MCMC).

To compare the breeds in general in terms of indices of genotypic and allelic diversity we used Friedman non-parametric test and to conduct pair-wise comparisons - Wilcoxon signed-rank test (with amendment for multiple comparisons while considering the level of significance). All the calculations were conducted in PAST (Hammer $\varnothing$ et al., 2001).

\section{RESULTS}

The actual number of genotypes for 11 MS-DNA loci, determined in horses of three breeds, was in the range from 8 (TB, locus HTG06) to 57 (USH, locus HMS03). In terms of specific breeds, the average number of genotypes was $26.0 \pm 1.9,15.4 \pm 1.6$ and $47.9 \pm 1.8$ for HB, TB and USH horses respectively (Table 4).

The distribution of genotype frequencies, used in the analysis of MS-DNA loci, was reliably different among the investigated breeds of horses (in most cases $-\mathrm{p}<0.001$ ), except for locus HTG07.

The evaluations of average genotypic diversity (average number of animals in the sampling with the same genotype) for different MS-DNA loci of horses from three breeds are presented in Figure.

Regardless of the fact that this index was found to be higher for loci HTG04, HMS06 and HTG06 in TB horses, in general no reliable differences were deter-

Table. 1. Composition of PCR-mixture (total volume of $15.0 \mu$ )

\begin{tabular}{l|c}
\hline \multicolumn{1}{c|}{ Mixture component } & $\begin{array}{c}\text { Per } 1 \\
\text { reaction, } \\
(\mu \mathrm{l})\end{array}$ \\
\hline PCR-buffer $5 \times$ blue $15 \mathrm{mM} \mathrm{Mg2+}$ & 2.5 \\
Mixture of deoxynucleotide triphosphates & 4.0 \\
$(\mathrm{dNTP}) 1.76 \mathrm{mM}$ & \\
Taq-polymerase $5 \mathrm{U} / \mu \mathrm{l}$ & 0.5 \\
Mixture of primers, $5 \mathrm{pM} / \mu \mathrm{l}$ each & 4.0 \\
Deionized water & 3.0 \\
DNA matrix & 1.0 \\
Total & 15.0 \\
\hline
\end{tabular}

Table 2. Conditions and parameters of amplification

Amplifiers with active temperature regulation (liquid volume in a tube $-15 \mu \mathrm{l}$ )

\begin{tabular}{c|c|c}
\hline Temperature, ${ }^{\circ} \mathrm{C}$ & Time & Number of cycles \\
\hline 95 & $10 \mathrm{~min}$ & 1 \\
95 & $30 \mathrm{~s}$ & 30 \\
60 & $30 \mathrm{~s}$ & \\
72 & $60 \mathrm{~s}$ & 1 \\
72 & $60 \mathrm{~min}$ & \\
\hline 4 & Storing \\
\hline
\end{tabular}


mined between specific breeds (Friedman test: $\chi^{2}=$ $=0.01 ; \mathrm{df}=2 ; \mathrm{p}>0.05)$.

Considerable differences were found in the number of breed-specific genotypes. The lowest average value (as per one locus) for $\mathrm{NG}_{\text {unik }}$ was noted for $\mathrm{TB}$ horses $(1.5 \pm 0.3)$ with the magnitude from 0 to 4 breed-specific genotypes. HB horses had more breed-specific genotypes (on average $-6.4 \pm 1.3$ with the magnitude from 1 to 14 genotypes per locus). USH horses had the highest values in terms of this index (on average $27.5 \pm 2.1$ with the magnitude from 18 to 36 genotypes per locus) (Table 1).

The share of breed-specific genotypes in the number of registered ones $\left(\mathrm{NG}_{\text {unik }} / \mathrm{NG}\right)$ varied in the range of $0.050-0.376,0-0.190$ and $0.429-0.875$ for horses of $\mathrm{HB}$, TB and USH respectively, and reliably $(\mathrm{p}<0.001-$ 0.05 ) differed in terms of specific loci (except for locus AHT04).
Potential genotypic diversity (at $n \rightarrow \infty$ ), evaluated using algorithm of Chao A. $\left(\mathrm{NG}_{\mathrm{Chao}}\right)$, also confirmed high level of diversity among USH horses, for which this value was $81.5 \pm 10.5$ genotypes on average per locus (Table 1). The second place in terms of the degree of potential genotypic diversity was given to HB animals ( $44.1 \pm 6.1$ genotypes per locus). However, TB horses were the most homogeneous group $(24.8 \pm 4.0$ genotypes per one locus). Therefore, there are reliable differences in the potential number of genotypes among horses of three investigated breeds (Friedman test: $\left.\chi^{2}=17.94 ; \mathrm{df}=2 ; \mathrm{p}<0.001\right)$. The results of pair-wise interbreed comparisons (in terms of specific MS-DNA loci) demonstrated that each breed is characterized by its unique level of potential genotypic diversity (Wilcoxon signed-rank test: in all cases $\mathrm{p}<0.05$ ).

In general, we registered the total of 162 alleles for 11 MS-DNA loci among the investigated breeds of horses.

Table 3. Microsatellite DNA-markers for identification of horses, used in the study

\begin{tabular}{|c|c|c|c|c|}
\hline $\begin{array}{l}\text { Name } \\
\text { of } \\
\text { marker }\end{array}$ & $\begin{array}{l}\text { Localization } \\
\text { in the } \\
\text { genome, } \\
\text { No of } \\
\text { chromosome }\end{array}$ & $\begin{array}{l}\text { Size of } \\
\text { alleles, } \\
\text { bp }\end{array}$ & $\begin{array}{c}\text { Structure } \\
\text { of microsatellite sequence }\end{array}$ & Sequence of primers \\
\hline HTG04 & 9 & $127-139$ & $\begin{array}{l}(\mathrm{TG}) \mathrm{nAT}(\mathrm{AG})_{5} \mathrm{AAG}(\mathrm{GA})_{5} \mathrm{ACAG} \\
(\mathrm{AGGG})_{3}\end{array}$ & $\begin{array}{l}\text { CTATCTCAGTCTTGATTGCAGGAC } \\
\text { СТСССТCССТСССТСТGTTCTC }\end{array}$ \\
\hline HMS06 & 4 & $151-169$ & $(\mathrm{GT}) \mathrm{n}$ & $\begin{array}{l}\text { GAAGCTGCCAGTATTCAACCATTG } \\
\text { CTCCATCTTGTGAAGTGTAACTCA }\end{array}$ \\
\hline HMS02 & 10 & $222-248$ & $(\mathrm{CA}) \mathrm{n}(\mathrm{TC})_{2}$ & $\begin{array}{l}\text { CTTGCAGTCGAATGTGTATTAAATG } \\
\text { ACGGTGGCAACTGCCAAGGAAG }\end{array}$ \\
\hline АHT04 & $24 q 14$ & $144-164$ & $(\mathrm{AC}) \mathrm{nAT}(\mathrm{AC}) \mathrm{n}$ & $\begin{array}{l}\text { AACCGCCTGAGCAAGGAAGTCCCA } \\
\text { GAGAGTTTACCCT }\end{array}$ \\
\hline ASB23 & $3 q 22.1-q 22$ & $128-154$ & $(\mathrm{TG}) \mathrm{n}$ and $(\mathrm{TG}) \mathrm{nTT}(\mathrm{TG})_{4}$ & $\begin{array}{l}\text { GAGGTTTGTAATTGGAATGGAGAA } \\
\text { GTCATTTTTAACACCT }\end{array}$ \\
\hline HTG07 & 4 & $118-128$ & $(\mathrm{TG})_{19}$ & $\begin{array}{l}\text { CCTGAAGCAGAACATCCCTCCTTG } \\
\text { ATAAAGTGTCTGGGCAGAGCTGCT }\end{array}$ \\
\hline HTG06 & $15 q 26-q 27$ & $84-102$ & $(\mathrm{TG}) \mathrm{n}$ & $\begin{array}{l}\text { GTTCACTGAATGTCAAATTCTGCT } \\
\text { CCTGCTTGGAGGCTGTGATAAGAT }\end{array}$ \\
\hline CA425 & $28 \mathrm{q} 18$ & $226-246$ & (GT)n & $\begin{array}{l}\text { AGCTGCCTCGTTAATTCA } \\
\text { CTCATGTCCGCTTGTCTC }\end{array}$ \\
\hline VHL20 & 30 & $87-105$ & $(\mathrm{TG})_{17}$ & $\begin{array}{l}\text { CAAGTCCTCTTACTTGAAGACTAG } \\
\text { AACTCAGGGAGAATCTTCCTCAG }\end{array}$ \\
\hline AHT05 & 8 & $126-144$ & (GT)n & $\begin{array}{l}\text { ACGGACACATCCCTGCCTGC } \\
\text { GCAGGCTAAGGGGGCTCAGC }\end{array}$ \\
\hline HMS03 & 9 & $148-170$ & $\begin{array}{l}(\mathrm{TG})_{2}(\mathrm{CA})_{2} \mathrm{TC}(\mathrm{CA}) \mathrm{n} \text { and } \\
(\mathrm{TG})_{2}(\mathrm{CA})_{2} \mathrm{TC}(\mathrm{CA}) \mathrm{nGA}(\mathrm{CA})_{5}\end{array}$ & $\begin{array}{l}\text { CCATCCTCACTTTTTCACTTTGTT } \\
\text { CCAACTCTTTGCACATAACAAGA }\end{array}$ \\
\hline HMS07 & $1 \mathrm{q} 25$ & $165-185$ & $(\mathrm{AC})_{2}(\mathrm{CA}) \mathrm{n}$ & $\begin{array}{l}\text { TGTTGTTGAAACATACCTTGACTGT } \\
\text { CAGGAAACTCATGTTGATACCATC }\end{array}$ \\
\hline ASB17 & $2 q 14 p 15$ & $87-129$ & $(\mathrm{AC}) \mathrm{n}$ & $\begin{array}{l}\text { ACCAGTCAGGATCTCCACCG } \\
\text { GAGGGCGGTACCTTTGTACC }\end{array}$ \\
\hline
\end{tabular}




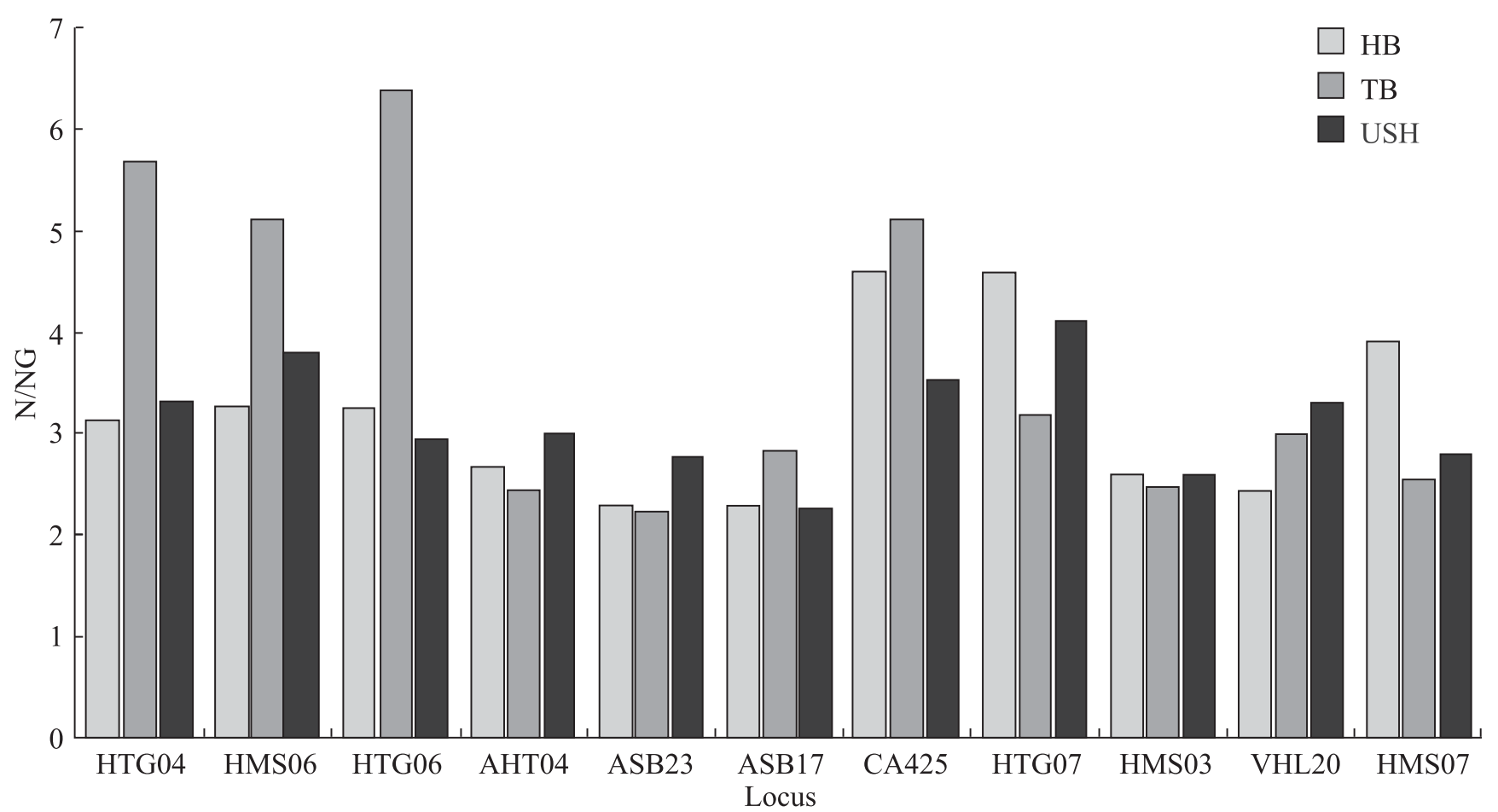

Fig. 1. The evaluations of the average number of animals with the same genotype (N/NG) for 11 MS-DNA loci of horses from three breeds

110 alleles were determined for HB horses, 88 alleles wfor TB horses, and 157 alleles - for USH horses. The results of the determined distribution of the number of alleles in terms of specific microsatellite loci among the horses of the analyzed breeds and the values of the average number of alleles per one locus are presented in Table 5.

Table 4. The evaluations of genetic diversity for 11 MS-DNA loci of horses from three breeds - number of genotypes (NG), number of breed-specific genotypes $\left(\mathrm{NG}_{\text {unik }}\right)$ and potential number of genotypes $\left(\mathrm{NG}_{\mathrm{Chao}}\right)$

\begin{tabular}{|c|c|c|c|c|c|c|c|c|c|c|c|}
\hline \multirow{2}{*}{ Locus } & \multicolumn{4}{|c|}{ Number of genotypes (NG) } & \multicolumn{4}{|c|}{$\begin{array}{l}\text { Number of breed-specific } \\
\text { genotypes }\left(\mathrm{NG}_{\text {unik }}\right)\end{array}$} & \multicolumn{3}{|c|}{$\begin{array}{c}\text { Potential number } \\
\text { of genotypes }\left(\mathrm{NG}_{\mathrm{Chao}}\right)\end{array}$} \\
\hline & $\begin{array}{c}\text { HB } \\
(n=78)\end{array}$ & $\begin{array}{c}\text { TB } \\
(\mathrm{n}=51)\end{array}$ & $\begin{array}{c}\text { USH } \\
(\mathrm{n}=152)\end{array}$ & $\mathrm{p}$ & HB & TB & USH & $\mathrm{p}$ & HB & TB & USH \\
\hline HTG04 & 25 & 9 & 46 & $* * *$ & 5 & 1 & 35 & $* * *$ & 28.5 & 11.3 & 82.5 \\
\hline HMS06 & 24 & 10 & 40 & $* * *$ & 4 & 1 & 18 & $*$ & 44.2 & 18.0 & 56.1 \\
\hline HTG06 & 24 & 8 & 52 & $* * *$ & 12 & 0 & 36 & $* * *$ & 28.5 & 8.0 & 70.6 \\
\hline АНT04 & 29 & 21 & 50 & $* * *$ & 8 & 4 & 21 & ns & 41.4 & 37.3 & 68.1 \\
\hline ASB23 & 34 & 23 & 51 & $* * *$ & 5 & 1 & 35 & $* * *$ & 48.2 & 30.1 & 67.7 \\
\hline ASB17 & 34 & 18 & 51 & $* * *$ & 10 & 3 & 29 & $* *$ & 79.1 & 24.0 & 99.3 \\
\hline CA425 & 17 & 10 & 43 & $* * *$ & 2 & 2 & 26 & $* * *$ & 21.5 & 10.0 & 70.0 \\
\hline HTG07 & 17 & 16 & 37 & ns & 3 & 1 & 20 & $* * *$ & 23.3 & 32.0 & 53.0 \\
\hline HMS03 & 30 & 17 & 57 & $* * *$ & 6 & 1 & 23 & $*$ & 78.2 & 27.1 & 100.6 \\
\hline VHL20 & 32 & 17 & 46 & $* * *$ & 14 & 1 & 24 & $* *$ & 56.1 & 52.3 & 54.7 \\
\hline HMS07 & 20 & 20 & 54 & $*$ & 1 & 1 & 35 & $* * *$ & 36.0 & 22.6 & 174.1 \\
\hline Mean & 26.0 & 15.4 & 47.9 & - & 6.4 & 1.5 & 27.5 & - & 44.1 & 24.8 & 81.5 \\
\hline \pm & 1.9 & 1.6 & 1.8 & - & 1.3 & 0.3 & 2.1 & - & 6.1 & 4.0 & 10.5 \\
\hline
\end{tabular}

Note: $*-\mathrm{p}<0.05 ; * *-\mathrm{p}<0.01 ; * * *-\mathrm{p}<0.001 ; \mathrm{ns}-\mathrm{p}>0.05$. 
Thus, the highest allelic diversity is also noted for USH horses (on average $14.3 \pm 0.51$ alleles per locus), whereas among HB and TB horses this index was lower $-10.0 \pm 0.50$ and $8.0 \pm 0.63$ alleles per locus, respectively.

The evaluations of the efficient number of alleles demonstrated a similar regularity (Table 2) and varied from $7.63 \pm 0.40$ (for USH horses) to $3.96 \pm 0.47$ (for USH horses) alleles on average per locus. The breeds had reliable differences in terms of evaluating this index in general (Friedman test: $\chi^{2}=18.48$; $\mathrm{df}=2$; $\mathrm{p}<0.001$ ), and as per results of pair-wise comparisons for specific loci (Wilcoxon signed-rank test: in all cases $\mathrm{p}<0.05)$.

To ensure accurate comparison of allelic diversity, we evaluated allelic diversity $\left(\mathrm{AR}_{50}\right)$ for 50 diploid animals (Table 5). The results obtained demonstrated higher level of allelic diversity for USH horses, whereas TB horses were characterized with the lowest values of this index.

Table 6 presents the list of the most common (with the frequency of over 0.20 ) alleles of 11 MS-DNA loci of horses from three breeds.

Therefore, five alleles (HMS06 ${ }^{169}$, AHT04 ${ }^{160}$, $\mathrm{ASB} 23^{132}, \mathrm{CA} 425^{240}$ and HTG07 ${ }^{128}$ ) were found to be the most common among the horses of three investigated breeds (Table 3) and may be specific for the species of Equus ferus caballus (L., 1758) in general.
In six more cases (HTG04 ${ }^{131}$, HTG06 ${ }^{84}$, ASB17 ${ }^{106}$, HTG0 $7^{126}$, HMS03 ${ }^{152}$ and HMS0 ${ }^{180}$ ) alleles were observed with high frequency in two out of three investigated breeds.

We registered rather a high level of allelic and genotypic variability and determined breed-specific alleles by locus VHL20

On the other hand, a great number of alleles was observed with very low frequency (under 0.05 ) among the analyzed breeds of horses. Such 44 alleles were noted for HB horses, 36 - among TB horses, and in USH they were 84 . It is noteworthy that the share of unique alleles served as a breed-specific index (Pearson's chi-square: $\left.\chi^{2}=6.06 ; \mathrm{df}=2 ; \mathrm{p}=0.048\right)$ and, while it was slightly above $40 \%$ for HB and TB horses, in more than half of USH horses $(53.6 \%)$ the alleles were observed with very low frequency.

As expected, the highest number of breed-specific alleles were noted among the investigated USH animals (Table 7).

On average, as per 50 randomly selected diploid animals, the number of breed-specific alleles $\left(\mathrm{PAR}_{50}\right)$ was $3.00 \pm 0.34$ alleles per locus for USH horses, whereas for $\mathrm{HB}$ and $\mathrm{TB}$ horses the relevant evaluations were one order lower $-0.34 \pm 0.12$ and $0.22 \pm 0.18$ alleles per locus, respectively (Table 2). The breeds had reliable differences in terms of evaluating this index in general

Table 5. The evaluation of allelic diversity for 11 MS-DNA loci of horses from three breeds - number of alleles (Na), efficient number of alleles $(\mathrm{Ae})$, allelic diversity $\left(\mathrm{AR}_{50}\right)$ and number of breed-specific alleles $\left(\mathrm{PAR}_{50}\right)$ for 50 diploid animals

\begin{tabular}{|c|c|c|c|c|c|c|c|c|c|c|c|c|}
\hline \multirow[t]{2}{*}{ Locus } & \multicolumn{3}{|c|}{$\begin{array}{c}\text { Number } \\
\text { of alleles }(\mathrm{Na})\end{array}$} & \multicolumn{3}{|c|}{$\begin{array}{l}\text { Effective number } \\
\text { of alleles (Ae) }\end{array}$} & \multicolumn{3}{|c|}{ Allele diversity $\left(\mathrm{AR}_{50}\right)$} & \multicolumn{3}{|c|}{$\begin{array}{c}\text { Number of breed-specific } \\
\text { alleles }\left(\mathrm{PAR}_{50}\right)\end{array}$} \\
\hline & HB & TB & USB & HB & TB & USB & $\mathrm{HB}$ & TB & USB & HB & TB & USB \\
\hline HTG04 & 10 & 5 & 13 & 4.78 & 3.00 & 8.35 & 9.81 & 5.00 & 12.07 & 1.10 & 0 & 3.36 \\
\hline HMS06 & 9 & 7 & 12 & 4.93 & 2.59 & 6.83 & 8.47 & 6.96 & 11.14 & 0.03 & 0 & 2.56 \\
\hline HTG06 & 11 & 7 & 15 & 4.78 & 2.23 & 7.89 & 10.13 & 6.92 & 13.88 & 0.79 & 0.04 & 2.84 \\
\hline АНТ04 & 11 & 9 & 15 & 6.63 & 6.65 & 8.23 & 10.62 & 8.98 & 13.76 & 0.20 & 0.09 & 2.47 \\
\hline ASB23 & 11 & 13 & 14 & 6.92 & 5.98 & 8.33 & 10.73 & 12.92 & 13.65 & 0.18 & 1.96 & 1.02 \\
\hline ASB17 & 13 & 8 & 16 & 6.45 & 5.00 & 10.04 & 11.98 & 8.00 & 15.04 & 0.06 & 0 & 2.77 \\
\hline CA425 & 7 & 7 & 16 & 3.57 & 1.92 & 5.26 & 6.64 & 6.94 & 13.37 & 0 & 0.30 & 5.72 \\
\hline HTG07 & 8 & 7 & 11 & 4.17 & 3.55 & 5.73 & 7.78 & 6.98 & 10.10 & 0.87 & 0 & 3.11 \\
\hline HMS03 & 10 & 10 & 16 & 5.16 & 3.36 & 8.41 & 9.87 & 9.98 & 13.98 & 0.13 & 0.01 & 3.27 \\
\hline VHL20 & 11 & 7 & 15 & 6.04 & 4.05 & 7.36 & 10.59 & 6.98 & 13.41 & 0.42 & 0 & 2.32 \\
\hline HMS07 & 9 & 8 & 14 & 4.37 & 5.25 & 7.47 & 8.27 & 8.00 & 12.10 & 0 & 0.02 & 3.52 \\
\hline Mean & 10.0 & 8.0 & 14.3 & 5.25 & 3.96 & 7.63 & 9.54 & 7.97 & 12.96 & 0.34 & 0.22 & 3.00 \\
\hline \pm & 0.50 & 0.63 & 0.51 & 0.33 & 0.47 & 0.40 & 0.47 & 0.63 & 0.43 & 0.12 & 0.18 & 0.34 \\
\hline
\end{tabular}


(Friedman test: $\chi^{2}=14.16$; df $=2 ; \mathrm{p}<0.001$ ). Pairwise comparisons for several loci demonstrated reliable differences for the pairs of HB-USH and TB-USH (Wilcoxon signed-rank test: in both cases $\mathrm{p}<0.05$ ).

The estimation of observed heterozygosity (Ho), expected heterozygosity (He) and inbreeding index (Fis) for 11 MS-DNA loci of horses from three breeds is presented in Table 8.

In general for the investigated breeds of horses, the values of observed heterozygosity varied from 0.314 (TB, locus CA425) to 0.914 (USH, locus VHL20). The average (for one investigated locus) value of heterozygosity was the highest for USH horses $-0.812 \pm 0.021$, and the lowest value of this index was noted for USH horses $-0.652 \pm 0.041$ (Table 5).

All three breeds, used in the analysis, had reliable differences in the level of heterozygosity in terms of specific loci (Friedman test: $\chi^{2}=10.91 ; \mathrm{df}=2 ; \mathrm{p}=0.043$ ), but in case of pair-wise comparisons the reliable differences were registered only among TB and USH horses (Wilcoxon signed-rank test: $\mathrm{p}=0.007$ ).

The indices of expected heterozygosity for all the investigated breeds in general varied from 0.478 (TB, locus CA425) to 0.900 (USH, locus ASB17). It should be noted that the evaluation of observed heterozygosity for horses of HB breed for six loci were found to be higher than the expected heterozygosity which conditioned negative values of the inbreeding index and demonstrated the excess of heterozygotes in this population.

On the contrary, the prevailing majority of MS-DNA loci in TB and USH horses (nine out of 11 investigated ones) demonstrated the deficiency of heterozygosity both in terms of specific loci and the breed in general - the average values of inbreeding index were $0.081 \pm 0.035$ and $0.062 \pm 0.019$, respectively, and were reliably exceeding the zero value (Table 5).

The presence of considerable deficiency of heterozygosity among horses of TB and USH breeds was confirmed by the results of checking the correspondence of the distribution of genotype frequencies to HardyWeinberg equilibrium (HWE) by 11 MS-DNA loci (Table 9).

Therefore, the number of loci with noted reliable deficiency of heterozygous genotypes for TB and USH horses was 6 and 7 (out of 11 under investigation) respectively.

In terms of specific loci, only HTG07 and HMS03 were noted for a considerably deficiency of heterozy- gosity in horses of all three investigated breeds, while for three more loci (AHT04, CA425 and HMS07) this deficiency was registered for animals of two out of three investigated breeds (Table 9).

On the other hand, it was determined that the distribution of genotypes of loci HTG06 and VHL20 did not deviate from Hardy-Weinberg equilibrium in all populations of the investigated animals.

Table 6. The list of common (the frequency over 0.20) alleles of 11 MS-DNA loci of horses from three breeds (in bp)

\begin{tabular}{c|c|c|c}
\hline Locus & HB & TB & USB \\
\hline HTG04 & 129,131 & 127,131 & 125 \\
HMS06 & $163, \mathbf{1 6 9}$ & $\mathbf{1 6 9}$ & $167, \mathbf{1 6 9}$ \\
HTG06 & 100 & 84,90 & 84 \\
AHT04 & $\mathbf{1 6 0}$ & $\mathbf{1 6 0}$ & $\mathbf{1 6 0}$ \\
ASB23 & $\mathbf{1 3 2}$ & $\mathbf{1 3 2}$ & $\mathbf{1 3 2}$ \\
ASB17 & 114 & 106 & 106 \\
CA425 & $\mathbf{2 4 0}$ & $\mathbf{2 4 0}$ & $\mathbf{2 4 0}$ \\
HTG07 & $120,126, \mathbf{1 2 8}$ & $126, \mathbf{1 2 8}$ & $\mathbf{1 2 8}$ \\
HMS03 & 160,166 & 152 & 152 \\
VHL20 & 87 & 95,97 & 93 \\
HMS07 & 174,180 & 178,180 & 176 \\
\hline
\end{tabular}

Note. Alleles, common for two breeds, are in italic, the ones, common for all three breeds, are in semi-bold.

Table 7. The list of breed-specific alleles for 11 MS-DNA loci of horses from three breeds (in bp)

\begin{tabular}{c|c|c|c}
\hline Locus & HB & TB & USB \\
\hline HTG04 & \multirow{2}{*}{139} & & $115,117,123,141$ \\
HMS06 & & & $151,153,173$ \\
HTG06 & 102 & & $78,80,106$ \\
AHT04 & & & $138,166,168$ \\
ASB23 & & 124,126 & 142 \\
ASB17 & & & $84,116,118$ \\
CA425 & & & $224,226,244,246,248,252$, \\
& & & 254,256 \\
HTG07 & 132 & & $110,112,114,116$ \\
HMS03 & & & $142,146,148,156,174$ \\
VHL20 & & & $79,81,107$ \\
HMS07 & & & $160,162,164,166,186$ \\
\hline
\end{tabular}




\section{DISCUSSION}

In the investigated Ukrainian populations of domestic horses, the most common ones (with the frequency over 0.45 ) were found to be 5 allelic variants $\left(\mathrm{HMS} 06^{169}, \mathrm{AHT} 04^{160}, \mathrm{ASB} 23^{132}, \mathrm{CA} 425^{240}\right.$, HTG07 ${ }^{128}$ ) which are most likely to be generally specific for the species of Equus ferus caballus (L., 1758). Six more (HTG04 ${ }^{131}$, HTG06 ${ }^{84}$, ASB17 ${ }^{106}$, HTG07 ${ }^{126}, \mathrm{HMS} 03^{152}$, HMS $07^{180}$ ) allelic variants were observed with high frequency $(>0.20)$ in two out of three investigated breeds, and one of them was Thoroughbred in all cases which, in our opinion, may demonstrate the input of the blood of Thoroughbred into the gene fund of the Ukrainian Hucul. We determined a high number of rare alleles (with the frequency up to 0.05 ), such 44 alleles were observed among Hucul horses, 36 - among Thoroughbred animals, and 84 - in Ukrainian Saddle Horses. It is noteworthy that the share of rare alleles turned out to be a breed-specific index (Pearson's chi-square: $\chi^{2}=6.06$; $\mathrm{df}=2 ; \mathrm{p}=0.048)$. While the share of rare alleles in HB and TB horses was slightly exceeding $40 \%$, in USH horses more than half $(53.6 \%)$ of alleles were observed with very low frequency.

The results obtained demonstrated that Ukrainian Saddle Horse was the most polymorphic among three Ukrainian populations of domestic horses of different breeds under our investigation. It was confirmed by the highest values of such indices of genetic variability as total and average number of determined alleles and genotypes, effective number of alleles; the share of breed-specific alleles and genotypes which was confirmed by the results of evaluating allelic diversity and potential number of the determined genotypes (Table 1,2).

The differences, determined among the breeds, were reliable by the indices of allelic and genotypic variability $(\mathrm{p}<0.05)$. The highest levels of observed $(\mathrm{Ho}=0.812)$ and expected $(\mathrm{He}=0.865)$ heterozygosity were noted for Ukrainian Saddle Horse along with the average level of population inbreeding (Fis $=0.062$ ). The prevailing majority of MS-DNA loci (nine out of 11 investigated ones) demonstrated the deficiency of heterozygosity both in terms of specific loci and the breed in general - the average values of inbreeding index were $0.062 \pm 0.019$ which was reliably exceeding zero. The reliable deficiency of heterozygous genotypes was noted for 7 out of 11 loci under investigation.

The most genetically consolidated investigated breed was found to be the population of Thoroughbred which was remarkable for the presence of animals with the same genotype by three out of eleven loci (HTG04, HMS06 and HTG04). The prevailing majority of loci (nine out of 11 under investigation) demonstrated the deficiency of heterozygosity both in terms of specific loci and the breed in general. For six of them, the deficiency of heterozygous genotypes was reliable. The average evaluation of inbreeding index was $0.081 \pm 0.035$

Table 8. The estimation of observed heterozygosity (Ho), expected heterozygosity (He) and inbreeding index (Fis) for 11 MS-DNA loci of horses from three breeds

\begin{tabular}{c|l|l|c|c|c|c|c|c|c}
\hline \multirow{2}{*}{ Locus } & \multicolumn{2}{|c|}{ Observed heterozygosity (Ho) } & \multicolumn{2}{c|}{ Expected heterozygosity (He) } & \multicolumn{3}{c}{ Index of inbreeding (Fis) } \\
\cline { 2 - 10 } & HB & TB & USB & HB & TB & USB & HB & TB & USB \\
\hline HTG04 & 0.808 & 0.588 & 0.783 & 0.791 & 0.667 & 0.880 & -0.021 & 0.118 & 0.111 \\
HMS06 & 0.808 & 0.647 & 0.796 & 0.797 & 0.614 & 0.854 & -0.013 & -0.054 & 0.067 \\
HTG06 & 0.692 & 0.608 & 0.855 & 0.791 & 0.552 & 0.873 & 0.125 & -0.102 & 0.021 \\
AHT04 & 0.910 & 0.765 & 0.789 & 0.849 & 0.850 & 0.879 & -0.072 & 0.100 & 0.101 \\
ASB23 & 0.859 & 0.824 & 0.816 & 0.856 & 0.833 & 0.880 & -0.004 & 0.011 & 0.073 \\
ASB17 & 0.885 & 0.706 & 0.901 & 0.845 & 0.800 & 0.900 & -0.047 & 0.118 & -0.001 \\
CA425 & 0.756 & 0.314 & 0.691 & 0.720 & 0.478 & 0.810 & -0.051 & 0.344 & 0.147 \\
HTG07 & 0.679 & 0.647 & 0.724 & 0.760 & 0.718 & 0.825 & 0.106 & 0.099 & 0.123 \\
HMS03 & 0.718 & 0.588 & 0.796 & 0.806 & 0.703 & 0.881 & 0.109 & 0.163 & 0.096 \\
VHL20 & 0.833 & 0.725 & 0.914 & 0.834 & 0.753 & 0.864 & 0.001 & 0.037 & -0.058 \\
HMS07 & 0.577 & 0.765 & 0.862 & 0.771 & 0.810 & 0.866 & 0.252 & 0.056 & 0.005 \\
Mean & 0.775 & 0.652 & 0.812 & 0.802 & 0.707 & 0.865 & 0.035 & 0.081 & 0.062 \\
\pm & 0.030 & 0.041 & 0.021 & 0.013 & 0.036 & 0.008 & 0.030 & 0.035 & 0.019 \\
\hline
\end{tabular}


and exceeded the zero value considerably. Thoroughbred, a breed of horses with low diversity, is notable for high average individual coefficient of inbreeding which may be related to population bottleneck effect, intense selective pressure or closed conditions of breeding during the long term of the breed history (Vázquez-Armijo JF et al., 2017, Putnová L et al., 2018).

Hucul breed was characterized by higher than average levels for all the investigated characteristics of genetic variability, except for the number of breed-specific genotypes and the share of breed-specific genotypes and alleles in the total number of the determined ones. The observed heterozygosity for horses of Hucul breed by six loci were higher than the expected heterozygosity which conditioned negative values of the inbreeding index and demonstrated the excess of heterozygotes in this population. The comparison of our results against the data of other researchers of Hucul breed demonstrated that our values of heterozygosity $(0.775 / 0.812)$ corresponded to the results, obtained for Czech (0.74/8.06) (Putnová L et al., 2018) and Polish Hucul (0.71/9.92) (Mackowski M et al., 2015) and exceeded the results, published for Romanian (0.66/6.58) (Georgescu SE et al, 2008), Austrian, Slovak and Hungarian Huculs (0.71/7.65) (Kusza S et al., 2013). The negative Fis values, determined for Hucul horses by 6 out of 11 microsatellite loci, demonstrated high intrabreed variability and lower heterozygosity (Putnova L et al., 2018). In our opinion, the determined specificities are related to local specific conditions of reproducing this breed.

In general, the specificities of the genetic structure of the investigated breeds by microsatellite DNA loci correspond to the history of formation of their gene funds.

\section{CONCLUSIONS}

The molecular and genetic analysis determined a high level of genetic consolidation of Thoroughbred horses $(\mathrm{Ho}=0.652 \pm 0.041$; Fis $=0.081 \pm 0.035$ ), which are bred with closed stud book. On the contrary, the horses of the newly created Ukrainian Saddle breed had the highest level of genetic variability $(\mathrm{Ho}=0.812$ \pm 0.021 ; Fis $=0.062 \pm 0.019$ ), which is explained by the openness of this population to "new blood" from other breeds that conditions the presence of the widest allelic spectrum. Hucul horses had rather a high level of all the investigated characteristics of genetic variability, which may serve as genetic proof of originality and old age of this breed. The presence of breed-specific allelic variants of microsatellite loci was determined for each investigated breed - HTG04 ${ }^{139}$, HTG06 ${ }^{102}$ and
Table 9. The results of checking correspondence to HardyWeinberg equilibrium for 11 MS-DNA loci for horses from three breeds

\begin{tabular}{c|c|c|c}
\hline Locus & $\mathrm{HB}$ & $\mathrm{TB}$ & USB \\
\hline HTG04 & $\mathrm{ns}$ & $\mathrm{ns}$ & $\mathrm{D}^{* * *}$ \\
HMS06 & $\mathrm{ns}$ & $\mathrm{ns}$ & $\mathrm{D}^{* *}$ \\
HTG06 & $\mathrm{ns}$ & $\mathrm{ns}$ & $\mathrm{ns}$ \\
AHT04 & $\mathrm{ns}$ & $\mathrm{D}^{* * *}$ & $\mathrm{D}^{* * *}$ \\
ASB23 & $\mathrm{ns}$ & $\mathrm{ns}$ & $\mathrm{D}^{*}$ \\
ASB17 & $\mathrm{ns}$ & $\mathrm{D}^{* * *}$ & $\mathrm{~ns}$ \\
CA425 & $\mathrm{ns}$ & $\mathrm{D}^{* *}$ & $\mathrm{D}^{* *}$ \\
HTG07 & $\mathrm{D}^{* * *}$ & $\mathrm{D}^{* *}$ & $\mathrm{D}^{* * *}$ \\
HMS03 & $\mathrm{D}^{*}$ & $\mathrm{D}$ & $\mathrm{D}^{* * *}$ \\
VHL20 & $\mathrm{ns}$ & $\mathrm{ns}$ & $\mathrm{ns}$ \\
HMS07 & $\mathrm{D}^{* *}$ & $\mathrm{D}$ & $\mathrm{ns}$ \\
\hline
\end{tabular}

Note. ${ }^{*}-\mathrm{p}<0.05 ; * *-\mathrm{p}<0.01 ; * * *-\mathrm{p}<0.001 ; \mathrm{ns}-$ $\mathrm{p}>0.05$. $\mathrm{D}-$ the deficiency of heterozygotes was noted.

HTG07 $7^{132}$ for Hucul horses, ASB23 $3^{124}$ and ASB23 $3^{126}$ for Thoroughbred, and from 1 by locus ASB23 to 8 by CA425 in Ukrainian Saddle Horse. In general, the application of the complex of mathematical approaches, suggested by us to conduct the population genetic analysis of genotyping results by microsatellite DNA loci both on individual and population levels, allows evaluating and forecasting microevolution processes during breed formation, controlling gene fund formation in the process of the breeding work and in the system of preserving genetic biodiversity.

Adherence to ethical principles. All the international, national and institutional principles of caring for animals and using them have been complied with.

Conflict of interests. The authors do not have any conflict of interests.

Financing. The work was done within research work of the department of molecular and diagnostic research of the Ukrainian Quality and Safety Laboratory for Agroindustrial Complex Products, the National University of Life and Environmental Sciences of Ukraine, on the topic "Molecular-genetic monitoring of pedigree cattle and horses using DNA markers" (DR 0108U001973) and the M.V. Zubets Institute of Animal Breeding and Genetics NAAS with the tasks: 24.01.01.01.F “To develop the methodology of evaluating the genotype of animals from cattle breeds, different in their productivity direction, using genes of quantitative traits" No. DR $0111 \mathrm{U} 003282$. 
Генетична структура коней різних порід за мікросателітними локусами ДНК

\author{
А.В. Шельов ${ }^{1}$, К.В. Копилов ${ }^{1}$, \\ С.С. Крамаренко ${ }^{2}$, О.С. Крамаренко ${ }^{2}$ \\ ${ }^{1}$ Інститут розведення і генетики тварин НААН, \\ с. Чубинське, Київська область, \\ вул. Погребняка 1, Україна, 08321 \\ ${ }^{2}$ Миколаївський національний \\ аграрний університет, Миколаїв, \\ вул. Георгія Гонгадзе 9, Україна, 54020 \\ e-mail: shelyov@gmail.com
}

Мета. Метою нашої роботи була оцінка генетичного різноманіття трьох порід свійських коней, що відрізняються як історією формування так і використання. Методи. Генотипування зразків ДНК трьох порід коней, а саме: гуцульської (78 гол.), англійської чистокровної (51 гол.) та української верхової (152 гол.), здійснювали за 11 мікросателітними локусами, рекомендованими Міжнародним комітетом 3 племінних книг (ISBC) та Міжнародним товариством 3 генетики тварин (ISAG). Для математичного аналізу було використано параметричні і непараметричні методи статистики. Результати. Вперше в Україні наведено результати аналізу поліморфізму генофондів коней гуцульської, англійської чистокровної та української верхової порід за 11 мікросателітними локусами ДНК. Продемонстровано, що дослідження мікросателітних локусів ДНК дає можливість не лише визначати достовірність походження племінних тварин, а й дає дозвіл здійснювати контроль популяційних процесів в різних породах та поліморфність самих порід. Висновки. В результаті проведення молекулярно-генетичного аналізу різних за історією походження порід коней встановлено специфічні особливості генетичної структури кожної з порід, які відповідають історії формування їхніх генофондів. Популяційно-генетичний аналіз за використання різних математичних методів рекомендовано 3 метою оцінювання і прогнозування мікроеволюційних процесів, контролю формування генофондів, як у процесі проведення селекційної роботи, так і в системі збереження генетичного біорізноманіття .

Ключові слова: коні, ДНК-маркери, мікросателіти, поліморфізм, алелофонд, генофонд, популяційна генетика.

\section{REFERENCES}

Bondarenko OV. (2008) The current state of Ukrainian ride breed of horses and ways of its preservation. Rozvedennja i genetyka tvaryn - Animal breeding and genetics. Kyiv. 49:224-231 (in Ukrainian).

Chao A. (1984) Non-parametric estimation of the number of classes in a population. Scandinavian J. Statistics. doi: 10.2307/4615964.

Derzhavna knyha pleminnykh koney hutsul's'koyi porody -
The Studbook of Hucul horses. Uzhhorod, Karpaty, 2013, 2:256 (in Ukrainian).

Georgescu SE, Manea MA, Costache M. (2008) The genetic structure of indigenous Romanian Hucul horse breed inferred from microsatellite data. Roman. Biotechnol. Letters 13:4030-4036.

Duru S. (2017). Pedigree analysis of the Turkish Arab horse population: structure, inbreeding and genetic variability. Animal. 11(9): 1449-56.

Gupta A, Bhardwaj Supriya A, Sharma P et al. (2015) Mitochondrial DNA - a tool for phylogenetic and biodiversity search in equines. J. Biodivers. Endanger. Species. doi: 10.4172/2332-2543.s1-006.

Hammer Ø, Harper DAT, Ryan PD. (2001) PAST: Paleontological Statistics Software Package for Education and Data Analysis. Palaeontol. Electron. 4:1-9.

Holovach MY. (2012) Selektsiyni aspekty zberezhennya henofondu koney hutsul's koyi porody. Naukovo-tekhnichnyy biuleten` Instytutu tvarynnytstva NAAN Ukrayiny - Scientific and technical bulletin of Institute of Animals of NAAS of Ukraine. Kharkiv. 106:44-49.

Khanshour A, Juras R, Blackburn R et al. (2015) The legend of the Canadian horse: genetic diversity and breed origin. J. Heredity. doi: 10.1093/jhered/esu074.

Kalinowski ST. (2005) HP-Rare: a computer program for performing rarefaction on measures of allelic diversity. Mol. Ecol. Notes. doi: 10.1111/j.1471-8286.2004. 00845.x.

Khare V, Khare A. (2017) Modern approach in animal breeding by use of advanced molecular genetic techniques. Inter. J. Livestock Res. doi: 10.5455/ ijlr.20170404010154.

Khrabrova LA, Blokhyna NV, Ustiantseva AV. (2014) Ynbrydynh y stepen homozyhotnosty mykrosatellytnykh lokusov u loshadei orlovskoi rysystoi porody. Selskokhoziaistvennaia byolohyia. doi: 10.15389/agrobiology. 2014.4.35rus.

Khrabrova LA, Blohina NV, Suleymanov OI et al. (2019) Assessment of line differentiation in the thoroughbred horse breed using DNA microsatellite loci. Vavylovskyi zhurnal henetyky y selektsyy. doi: 10.18699/ VJ19.526

Kusza S, Priskin K, Ivankovic A et al. (2013) Genetic characterization and population bottleneck in the Hucul horse based on microsatellite and mitochondrial data. Biol. J. Linnean Soc. doi:10.1111/bij.12023.

Mackowski M, Mucha S, Cholewinski G et al. (2015) Genetic diversity in Hucul and Polish primitive horse breeds. Arch. Animal Breed. doi: 10.5194/aab-58-232015.

Peakall R, Smouse PE. (2012) GenAlEx 6.5: genetic analysis in Excel. Population genetic software for teaching and research-an update. Bioinform. doi:10.1093/bioinformatics/bts 460 .

Putnová L, Štohl R, Vrtková I. (2018) Genetic monitoring of horses in the Czech Republic: A large-scale study with 


\section{GENETIC STRUCTURE OF DIFFERENT EQUINE BREEDS BY MICROSATELLITE DNA LOCI}

a focus on the Czech autochthonous breeds. J. Anim. Breed. Genet. doi: 10.1111/jbg.12313.

Putnová L, Štohl R, Vrtková I. (2019) Using nuclear microsatellite data to trace the gene flow and population structure in Czech horses. Czech J. Anim. Sci., doi: 10.17221/2/2018-CJAS.

Rousset F. (2008) Genepop'007: a complete reimplementation of the Genepop software for Windows and Linux. Mol. Ecol. Resources. doi: 10.1111/j.1471-8286. 2007.01931.x

Rukavina D, Hasanbašic D, Pojskic N et al. (2015) Analysis of genetic diversity among certain horse breeds from Bosnia and Herzegovina. Veterinaria 64(1):25-9

Seyedabadi HR, Kazemi E. (2017). Genetic characterization and assessment of demographic bottleneck in Caspian horse population. Cell. mol. biol. (Noisy-leGrand, France). 63(11):92-6. doi: 10.14715/cmb/2017. 63.11 .16$. van de Goor LHP, van Haeringen WA. (2010) A proposal for standardization in forensic equine DNA typing: allele nomenclature for equine-specific STR loci. Anim. Genet. 41(2):122-7. doi: 10.1111/j.1365-2052.2009.01975.x.

Vázquez-Armijo JF, Parra-Bracamonte GM, Velazquez MA et al. (2017) Diversity and effective population size of four horse breeds from microsatellite DNA markers in South-Central Mexico. Arch. Anim. Breed. doi: 10.5194/ aab-60-137-2017.

Vostrá Vydrová H, Vostrý L, Hofmanová B et al. (2015) Population studies of Czech Hucul horses. PoljoPrivreda 21(1):41-3.

Winton CL, Hegarty MJ, McMahon R et al. (2013) Genetic diversity and phylogenetic analysis of native mountain ponies of Britain and Ireland reveals a novel rare population. Ecol. Evol. doi:10.1002/ece3.507. 